\title{
Water Quality Modeling of Bhima River by using HEC-RAS Software
}

\author{
Pooja D. Taralgatti, R. S. Pawar, G. S. Pawar, Majeed Hazza Nomaan, C. R. Limkar
}

\begin{abstract}
The River has got religious importance in India. The Bhima River is beginning from Bhimashankar hill and it flows through some parts of Maharashtra and Karnataka state. The assessment of water quality for the development of the places near the bank of River is important. These is controlled by various manmade activities. The quality of river water resources is facing problems because of the continuous agricultural runoff, development and urbanization. Due to mixing of nutrients causes algal blooms, which results eutrophication. The modeling of water quality can be deliberated as useful tool for assessing river water. Bhima River is demarcated as a major and important water body located in Pandharpur, dist. Solapur, Maharashtra. As Pandharpur is having historical background and known as one of the famous Holly places in Maharashtra, this place is facing huge population fluctuation due to migrated pilgrims and rapid growth of urbanization. These two things detrimentally affect River water quality. The main objective of current study was to develop a hydrodynamic model combined with river water quality model for the Bhima River to measure and recognize the processes harmful for the River. For Bhima River a hydrodynamic model was constructed using the HEC-RAS 4.1 software combined with a river water quality model to estimate the amount, distribution and sources of algae, nitrate and temperature. The river model has standardized with the help of previous water levels near the Pandharpur region. It has standardized and calibrated for the assessed parameters by competing them with the present data. The result showed a relationship between $D O$ and temperature range. DO level in Pandharpur and Gopalpur were observed to be fluctuating with respective temperature and during Vari season. However, wastewater discharge from Nalha in sample station 3 i.e. Goplapur shows slit changes in DO and due to this there is necessity to learn other parameters also.
\end{abstract}

Index Terms: Hydrodynamic, Water Quality Modeling, Bhima River, Pandharpur, etc.

\section{INTRODUCTION}

Water is one of the supreme fundamental need that nature provides to maintain life for all the living organism including human being. Water is the main essential natural medicine of life. It is considered to be the stimulator of the cultural and socio-economic development of humanity on world [1].

Revised Manuscript Received on February 05, 2020.

* Correspondence Author

Prof. P.D. Taralgatti*, Assistant Professor in SVERI's College of Engineering Pandharpur

Dr. R.S. Pawar, Assistant Professor in SVERI's College of Engineering Pandharpur Email: ranjitsinhpawar@rediffmail.com

Prof. G.S. Pawar, Assistant Professor in SVERI's College of

Dr. Majeed Hazza Nomaan, Assistant Professor in Faculty of Education and Science, Amran University,

Prof. C. R. Limkar, Assistant Professor in SVERI's College of Engineering Pandharpur

(c) The Authors. Published by Blue Eyes Intelligence Engineering and Sciences Publication (BEIESP). This is an open access article under the CC BY-NC-ND license (http://creativecommons.org/licenses/by-nc-nd/4.0/) Engineering Pandharpur

As we know rain is the main source of water which is afterwards gets converted into surface water and ground water sources. We are utilizing both of these main sources to fulfill our basic needs. After utilization of such resources we introduce one of the important problems called water pollution, which is triggered by increased industrialization, urbanization on the bank of river lead to contaminate the river water. Furthermore, this lack of solid waste management practices, open defecation and extensive use of pesticides and fertilizers mixed into surface water and increases pollution.

River water is major water resource considered in India. Rivers are useful for our sustenance of life and we have the liability of preserve it. It is to make our development and consequently quality of life sustainable. River does not pollute from its origin, but some areas in rivers are polluted and some preventive actions are taken for that conditions.

In India there are thirteen main river basins (area greater than 20000 sq.km.), which occupy $82.4 \%$ of total drainage basins, contribute $85 \%$ of total surface flow and house $80 \%$ of the population. These major river basins include Indus, Brahmaputra, Godavari, Ganga, Mahanadi, Krishna, Narmada, Brahmini, Cauvery, Mahi, Tapi, Sabarmati and Pennar. The categorization of all river basin as per there catchment area considers main river basins of area more than 20,000 Sq. Km in percentage, medium river basins having area between 2000-20,000 Sq. Km in percentage and small river basins as area smaller than $2000 \mathrm{Sq}$. Km in percentage. There are some desert rivers, that flow in less distance and get missing in deserts. The medium and small river basins are primarily in coastal area and counted as 28 and 52 respectively. The study area covers all Pandharpur Taluka specially where festive season carries more population burden on town such as Pandharpur, Gopalpur villages. In this area the Bhima River is known as Chandrabhaga.

\section{MATERIALS AND METHODS}

\subsection{Data collection}

a) Geometric Data: This data mainly includes geometric data of selected research area which was collected from Irrigation and Pat-bhandhare Pandharpur division. In addition to this Google Earth was the main engine in this type of data collection.

b) Steady Flow data: Second type of data required is flow or discharge data of selected research area. For this research work the discharge data is collected form hydrological project HDUG Nashik. This data is necessary to generate flow profile as well as calculation of critical depth. 


\section{Water Quality Modeling of Bhima River by using HEC-RAS Software}

\subsection{Water sample collection for water quality modeling}

The five locations are marked for water sample collection. To compute the water quality simulation, data were generated by performing water quality parameter test on collected water samples.

The $\mathrm{pH}$, Electrical Conductivity (EC), Dissolved Oxygen (DO), Sodium (Na), Temperature, Algae and Nutrients. Following test were conducted on water sample:

a) DO (Dissolved Oxygen):

Water sample were collected in 200ml BOD bottle with stopper from every five-sample station from month of May to October 2017 covering all the seasons. Onsite DO fixation was made by adding Alkali axide solution and MnSO4 solution in it. After giving time for settlement to brown precipitate, con. $\mathrm{HCl}$ of $2 \mathrm{ml}$ is added in BOD bottle to dilute all the precipitate and make solution ready for titration with sodium thiosulphate.

b) Temperature: The temperature value was taken from five stations was for both water and air temperature. Simple thermometer were used for detecting the temperature in all stations. Most of the samples were collected during afternoon in between 11.30 to $1.00 \mathrm{PM}$.

c) Algae: To collect algael sample $200 \mathrm{ml}$ sample was filtered from smallest 750 micron sieve on the site. Then add $3 \mathrm{ml}$ iodine solution to fix the algael content in it. Store this sample in plastic can and take reading as easily as possible.

d) Nutrients; This were tested on spectrophotometer to analyst the result.

e) Other tested parameter in lab: $\mathrm{pH}$ by $\mathrm{pH}$ meter, conductivity by conductivity meter, sodium content by spectrophotometer.

\subsection{Methods used}

For simulating any parameter whether it is water quality or hydrological parameter are is a requirement of common primary input data in the form of discharge data, River cross sections, flow rates etc. The data collection and requirements will vary according to the aim of research. For example, for modeling water quality data one must have water sample test results in addition to that for River reach study other data is also required such as river critical dept, cryosections, discharges etc.

\section{DEVELOPMENT OF GEOMETRIC PROFILE:}

The schematic of selected river was prepared by adding a station image from Google Earth and manually developed river reaches in HEC-RAS 4.1 geometric data editor with the center line points (Figure 4). After, the 68 cross sections data have been inputted from Google Earth along with their manning value of 0.010 for the chief channels and of 0.02 to 0.050 for the floodplains i.e. left overbank and right overbank area. The manning's values were adjusted for the calibration reasons [15].

\section{Boundary condition data input for water quality data} window in HEC RAS 4.1.

\begin{tabular}{|l|c|c|}
\hline $\begin{array}{l}\text { Boundary stations as per } \\
\text { cross section }\end{array}$ & $\mathbf{9 7 8 4 9 4}$ & 548387 \\
\hline
\end{tabular}

\begin{tabular}{|l|c|c|}
\hline Water Quality Parameter & Temperature & DO \\
\hline 28 May, 2017 & 24 & 10 \\
\hline 13 June, 2017 & 25 & 8 \\
\hline 15 July, 2017 & 24 & 5 \\
\hline 13 August, 2017 & 25 & 4 \\
\hline 13 September, 2017 & 25 & 6.9 \\
\hline 10 October, 2017 & 24 & 8.35 \\
\hline
\end{tabular}

\subsection{Development of Water Quality Profile:}

To perform water quality modeling in HEC RAS, Temperature, nutrient and meteorological data were put as input. The boundary conditions are also necessary here to define the cell length of model as well to perform computation of water quality data in minimum time and accurate manner.

\subsection{Water quality data and Boundary Condition:}

The data for boundary conditions is written for temperature values, test result for algae, DO and nutrient such as NO3 and prosperous. Theses boundary condition will be base for further water quality computation. Table 3 represents boundary conditions for different parameters temperature, nutrients and algae.

\section{Meteorological Parameter Information entered} water quality data editor in HEC RAS 4.1.

\begin{tabular}{|c|c|c|c|c|c|}
\hline $\begin{array}{c}\text { Meteorologi } \\
\text { cal Station }\end{array}$ & $\begin{array}{c}\text { Atm. } \\
\text { Pressure } \\
\mathbf{( m b )}\end{array}$ & $\begin{array}{c}\text { Temp. } \\
\mathbf{( { } ^ { 0 } \mathbf { C } )}\end{array}$ & $\begin{array}{c}\text { Humidity } \\
\mathbf{( m b )}\end{array}$ & Cloudiness & $\begin{array}{c}\text { Wind } \\
\text { Speed } \\
\mathbf{( m / s )}\end{array}$ \\
\hline $28 / 05 / 2017$ & 1006 & 30 & 49 & 0 & 7 \\
\hline $10 / 06 / 2017$ & 1006 & 33 & 84 & 0.79 & 6 \\
\hline $13 / 07 / 2017$ & 1009 & 30 & 65 & 0.79 & 6 \\
\hline $15 / 08 / 2017$ & 1011 & 28 & 73 & 0.59 & 4 \\
\hline $17 / 09 / 2017$ & 1008 & 27 & 81 & 0.47 & 4 \\
\hline $28 / 10 / 2017$ & 1014 & 26 & 46 & 0.63 & 3 \\
\hline $10 / 11 / 2017$ & 1013 & 25 & 46 & 0.04 & 3 \\
\hline
\end{tabular}

\section{RESULT AND DISCUSSION}

The accurateness of a Hydrodynamic Model is depending on accuracy of input data means meteorological information, cross sections and thus the quality of model prepared in this study has limited to the accuracy of provided data. The final results are showed in the detail in above tables. That cross section final computed profile shows the maximum channel depth of $2.16 \mathrm{~m}$ occurred at Gursale starting point of reach. The depth is minimum of $1.69 \mathrm{~m}$ occurred at the downstream end at Mundhevadi which is last station. The result shown that the maximum velocity at the upstream side of the river is $3.06 \mathrm{~m} / \mathrm{s}$ and the minimum velocity at the downstream is 1.74 $\mathrm{m} / \mathrm{s}$.

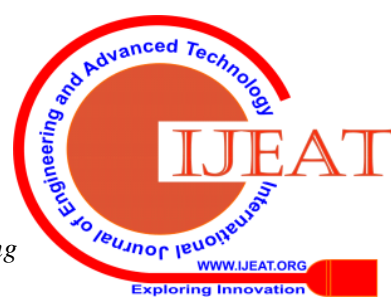


The flux is found to be small from upstream to downstream, whereas the retention time is high within the Pandharpur region.

\section{Observed input data Vs Computed output result}

\begin{tabular}{|l|c|c|c|c|c|c|}
\hline \multirow{2}{*}{ Sample Station } & \multicolumn{3}{|c|}{ Observed Value } & \multicolumn{3}{c|}{ Computed Value } \\
\cline { 2 - 7 } & $\begin{array}{c}\text { Temp. } \\
\left({ }^{0} \mathbf{C}\right)\end{array}$ & Algae & $\begin{array}{c}\text { Nitrate } \\
(\mathbf{p p m})\end{array}$ & $\begin{array}{c}\text { Temp. } \\
\left({ }^{0} \mathbf{C}\right)\end{array}$ & Algae & $\begin{array}{c}\text { Nitrate } \\
(\mathbf{p p m})\end{array}$ \\
\hline Gursale & 24.1 & 1.06 & 1.91 & 24.38 & 1.180 & 1.94 \\
\hline Pandharpur & 24.02 & 1.15 & 1.85 & 24.5 & 1.12 & 1.868 \\
\hline Gopalpur & 22.5 & 1.01 & 2.02 & 23.43 & 1.02 & 2.2 \\
\hline Ajunsond & 24.22 & 1.02 & 1.6 & 25.02 & 1.09 & 1.7 \\
\hline Mundhevadi & 24 & 1.03 & 1 & 25.57 & 1.05 & 1 \\
\hline
\end{tabular}

The above table shows the observed input data and computed output data of all the sample stations. The temperature, Algae and Nitrate results have shown in this table.

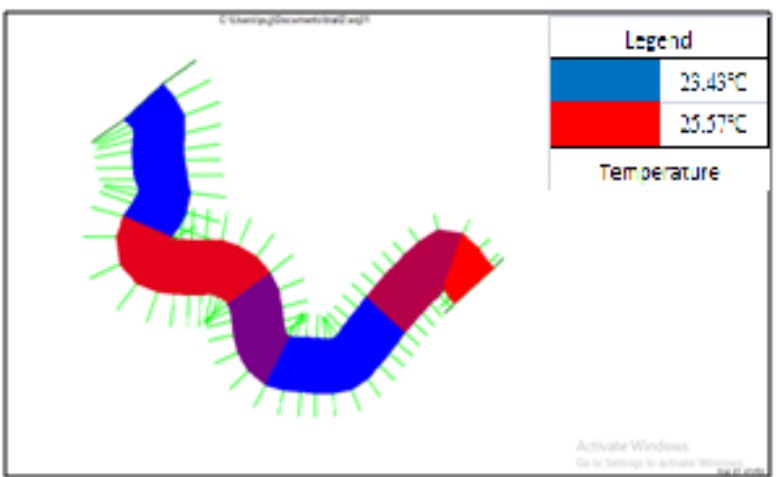

Fig (1): Schematic for Water Parameter Temperature

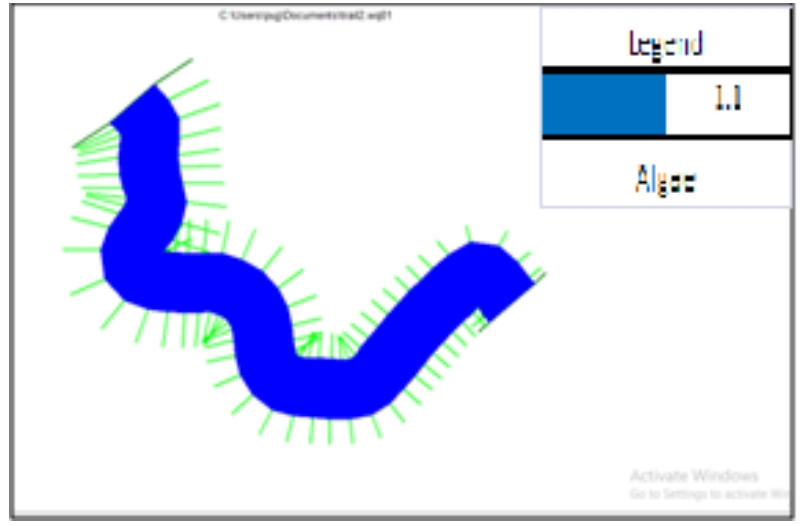

Fig. (2): Schematic for water parameter Algae

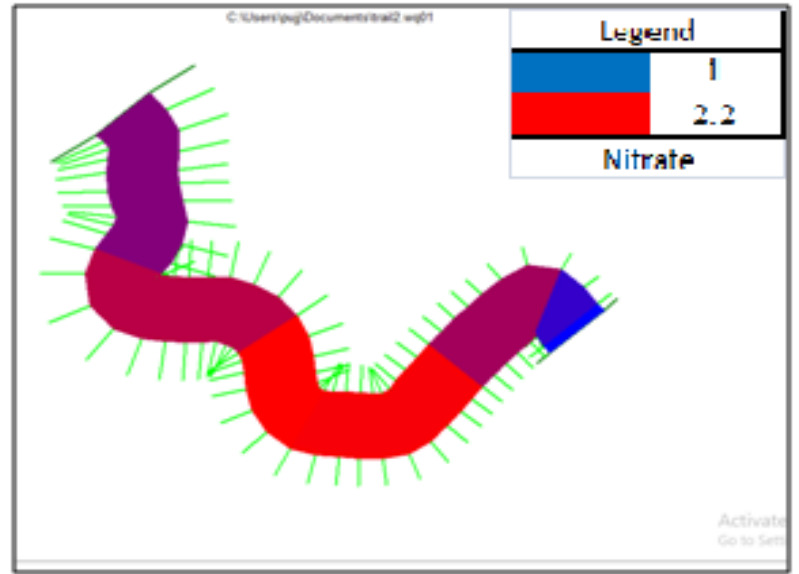

Fig. (3): Schematic for water parameter NO3

\section{CONCLUSION:}

A steady state hydraulic model combined with a water quality model for Bhima (Chandrabhaga) River is developed. The hydro-dynamic and water quality model were referenced with the available historic data for sample stations from HDUG and MPCB generated reports. The model authentication was started on the hydrodynamic model and water quality parameters by carrying out sensitivity analysis.

The model was verified and calibrated by assessing the simulated water quality results with the observed water quality data for five various sites nearer to Pandharpur. The water quality final results were assessed for the Temperature, Algae and Nitrate. The nitrate concentration increased towards Gursale and Gopalpur sample station. while algae have the reverse pattern at this station. This is happened may be because of the wastewater Nala is meeting to river reach in this area which increases the nutrient concentration in this area. With the help of water quality analyses, it can be seen that Pandharpur and Gopalpur are the most polluted stations

\section{REFERENCES}

1. Ahmad Shahiri Parsa, Mohammad Noori, Mohammad Heydari and Mahmood Rashidi, "Floodplain Zoning Simulation by Using HEC-RAS and CCHE2D Models in the Sungai Maka River".

2. Arun Kansal, Deepshikha Sharma, "Water quality analysis of River Yamuna using water quality index in the national capital territory", India (2000-2009)

3. A. Muhammetoğlu and S. Soyupak, "A three dimensional water quality macrophyte interaction model for shallow lakes," Ecological Modelling, vol. 133, no. 3, pp. 161-180, 2000.

4. Burak Öterler, Timur Kirgiz, Meric Albay, "Seasonal Variations of Water Quality Parameters and Algal Flora of Tundzha (Tunca) River", (Edirne, Turkey) Open Journal of Ecology, 2014, 4, 807-819.

5. Basappa. B. Kori1, T.Shashidhar \& Shashikanth Mise," application of automated qual $2 \mathrm{kw}$ for water quality modeling in the river karanja, india", g.j.b.b., vol.2 (2) 2013: 193-203

6. Central water commission report 2011

7. D. A. Chain, Water-Resources Engineering, Pearson Prentice Hall, 2006. (online)

8. Leena Deshpande, "water quality analysis methods".

9. Didem Gökçe, "Algae as an Indicator of Water Quality". (research-article)

10. Disprtion cofficint consept (available online) on www.epa.gov/athens/wwqtsc/courses/wasp7/transport/Dispersion.ppt

11. Evan G.R. Davies a, Slobodan P. Simonovic, "Global water resources modeling with an integrated model of the social-economic-environmental system ".

12. Hussien. M. EL-Shafei, "Some Heavy Metals Concentration in Water, Muscles and Gills of Tilapia Niloticus as Biological Indicator of Manzala Lake Pollution “.

13. Heba Hussien," WATER QUALITY MODELING OF DUBAI CREEK USING HEC-RAS",

14. "How Hydrodynamic Models Are Used," Office of Cost Survey, [Online].

Available:

http://www.nauticalcharts.noaa.gov/csdl/learn_models.html. [Accessed 18 April 2017].

15. J. Yisa and T. Jimoh," Analytical Studies on Water Quality Index of River Landzu".

16. Meteorological Pandharpur Data (online available) https://www.worldweatheronline.com/lang/en-in/pandharpur-weather history/maharashtra/in.aspx

17. Mohan Kodarkar, Sandeep Joshi, Sayali Joshi "Ujjani Reservoir in Pune District, Maharashtra, India: A World Lake,Vision Candidate Waiting for Ecological Restoration" world bank 2005. 
18. M.M. Aral, Environmental Modeling and Health Risk Analysis (ACTS/RISK), DOI 10.1007/978-90-481-8608-2_2, \# Springer Science Business Media B.V. 2010

19. M.S.Kodarkar, Vidyanand Ranade, Sandeep Joshi,” integrated lake basin management (ilbm) - a case study of yeshwantsagar (ujjani), maharashtra, india", ILBM : Upper Bhima Basin (UBB) and Ujjani reservoir : $1-13$

20. Orchir Alnasukh, “Analytical Studies on Water Quality Index of River Landzu”2008

21. Pandurang bidkar, "flood analysis of river bhima between ujjani dam and confluence with river man" 2013

22. Richard P. Stumpf and Kristine Holderied," Determination of water depth with high-resolution satellite imagery over variable bottom types", NOAA National Ocean Service, Center for Coastal Monitoring and Assessment, 1305 East-West Highway rm 9115, Silver Spring, Maryland 20910

23. Report on Water Quality "Hot Spots" in Rivers of India (Central Water Commission,New Delhi, Aug, 2011))

24. Real Time Stream Flow Forecasting and Reservoir Operation System for Krishna and Bhima River Basins in Maharashtra (RTSF \& ROS), Government of Maharashtra, Hydrology Project II, Water Resources Department IBRD Loan No: 4749-IN

25. Sandeep Joshi, Sayali Joshi," Ujjani Reservoir in Pune District, Maharashtra, India: A World Lake Vision Candidate Waiting for Ecological Restoration",

\section{AUTHORS PROFILE}

Prof. P.D. Taralgatti, M.E. (Environment Engineering) and Working as Assistant Professor in SVERI's College of Engineering Pandharpur and having 5 years' experience in teaching.

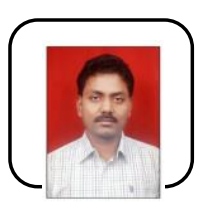

Dr. R.S. Pawar, M.Sc. PhD, SET (Environment Science) working as Assistant Professor in SVERI's College of Engineering Pandharpur and having 10 years' experience in teaching and Research.

Email: ranjitsinhpawar@rediffmail.com

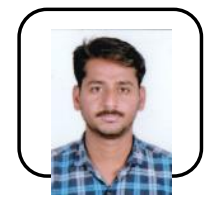

Prof. G.S. Pawar, M.Sc. (Applied Geology) and Working as Assistant Professor in SVERI's College of Engineering Pandharpur and having 1 years' experience in teaching

Dr. Majeed Hazza Nomaan, M.Sc. Ph.D. (Environmental Science) and Working as Assistant Professor in Faculty of Education and Science, Amran University, Republic of Yemen and having 10 years' experience in teaching and Research.

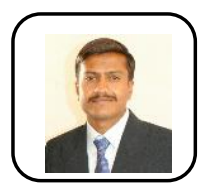

Prof. C. R. Limkar, M.Tech. (Transportation) and Working as Assistant Professor in SVERI's College of Engineering Pandharpur and having 6 years' experience in teaching. 